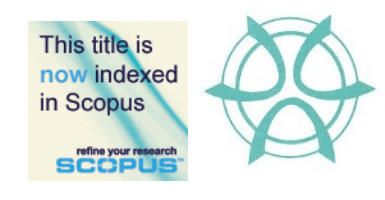

\title{
THE DEVELOPMENT CONTROL OF URBAN CENTRE IN KUALA LUMPUR
}

\author{
Izuandi Yin ${ }^{1}$, Jamalunlaili Abdullah ${ }^{2}$ \\ ${ }^{I}$ School of Housing Building and Planning \\ UNIVERSITI SAINS MALAYSIA \\ ${ }^{2}$ Faculty of Architecture, Planning \& Surveying \\ UNIVERSITI TEKNOLOGI MARA
}

\begin{abstract}
Development control is the major factor that contributes to the growth of urban centres in Kuala Lumpur City Centre. This paper focuses on the development control in urban centres that faces the challenge of identifying the limit of the development growth's boundary. The scope is identifying the growth rank in Kuala Lumpur prior to the existing physical development. This study is aimed at the function of development control in measuring the ranking of the growth centres in Kuala Lumpur. This has resulted in the ranking of 11 growth centres chosen for this study in Kuala Lumpur. The objectives of this study are to identify the growth level from the urban centre's location and to examine the influence of tools of development control such as built up area towards the development growth. The study uses the qualitative and quantitative methods such as allocation of development intensity in defining the growth of an urban centre in Kuala Lumpur. The study analyses the land use, built-up area, floor space optimisation, total plot ratio, gross development value, and density requirements to find the implementation of intensity of development, zoning of land use, high-density development, and the correlative relation of development control with the growth centre. This study is anticipated to enhance the establishment of land use management and physical development in Kuala Lumpur City Centre for sustainable urban growth and proper management of development control.
\end{abstract}

Keywords: urban growth, development control, growth center, urban development, built-up area.

\footnotetext{
${ }^{1}$ Lecturer at Universiti Sains Malaysia Email: izuandi.yin@usm.my
} 
Izuandi Yin, Jamalunlaili Abdullah

The Development Control of Urban Centre in Kuala Lumpur

\section{INTRODUCTION}

Eleven Growth Centres are selected in Kuala Lumpur for this study based on the growth's hierarchy and their own ranks. This study explains the analysis of development control for each growth centre. These growth centres need to be ranked and classified by measuring the urban economic growth to get the finding for each growth development. The objectives in this study are the identification of the urban growth pattern that leads to the limitation of development border in Kuala Lumpur, examining the influence of development control towards the growth of urban centres, and analysing the location decision and the intensity of development in an area which uses the tools of development control that have an impact on high-density development in Kuala Lumpur. Urban growth development is related to several themes such as development control for intensity of development. This research has identified some tools of development control that influence the growth of the Kuala Lumpur commercial city centre, the surrounding seven district centres and three neighbourhood centres. There are five tools of development control which will be analysed in this study; the size of land use area, built up area, plot ratio, gross development value, and floor space.

\section{DEVELOPMENT CONTROL IN URBAN AREA}

Act 172 under Part IV has clearly explained the planning control and mentioned some tools of development control which approve the development (through planning permission) that can be conveyed into change of land use, building and development intensity. Section 19 (2) of Act 172 also mentioned that building alterations must undergo planning permission. Most buildings have been altered to increase building height and floor area, which automatically results in a greater built up area. The development control of Kuala Lumpur has led to the growth of urban centres by rank which aims to control the land and building development and is one of the elements to process and assess the application before the planning permission (either permanent or temporary) is granted for further land development (Yusup. M, et al., 2018). Planning permission is part of urban management procedures, and the current system used for accepting or refusing any development in every local authority in Malaysia (Quigley, 2006). In general, the development of urban centres can be seen from the point of land use optimisation in the context of the intensity of land uses as well as decision of firm's location (Siedentop et al., 2016).

\section{PROBLEM STATEMENT}

The National Urbanisation Plan 2 (NUP2, 2016) has mentioned the issues of urban sprawl and limitation of city borders for every city in Malaysia. The major problem is identifying the limitation of the boundary. Because of the high intensity of development, the sprawl of development towards the suburbs cannot 
be defined explicitly using the tools of development control. Based on Kuala Lumpur City Plan 2020 , the growth of the Kuala Lumpur City Centre or in the classification of land use zone called City Centre Commercial (CCC) as a workplace which expands and links up to the suburb areas while massive urbanised area occupied by residential buildings in the District Commercial Centre (DCC). However, the development growth in the boundary between the CCC and DCC somehow still isn't properly identified. The urban sprawl issue in Malaysia can be solved with the National Urbanisation Plan 2 (NUP2, 2016). In 2025, an estimated total of 314 cities in Malaysia will have a clear urban boundary thus solving the problem of urban sprawl and the provision of public facilities.

The allocation of development control for CCC development within the DCC development gave different priorities and growth for some areas. At some point we are unable to tell which is the actual area for the urban centre and which is the district centre to be considered in KL City. The district centre is more prominent than the city centre because of the high density of development. This might cause a misunderstanding of the primary development area for the CCC and secondary development areas for district centres in KL City. Kuala Lumpur City Plan 2020 refers to the urban growth from the centre but in the current situation at the physical site, it seems that other locations considered as the district centres also have high-density development and the built-up area is almost the same with the city centre.

The planned MRT project and other mega projects elsewhere have attracted a lot of attention especially in the city centre and other district centres. This Transit Oriented Development in the City Centre attracts more developments with high built up area densities in the Kuala Lumpur City Centre. A major project in Greater KL is the Tun Razak Exchange which is an iconic 70acre development with an estimated RM40 billion in Gross Development Value located strategically in the Golden Triangle and inside the CCC (Prime Minister's Department, 2016). The potential development of an urban area should be properly planned in line with technological changes and global challenges to maximise its contribution to national economic growth. By using some technological method, the urban growth can be defined systematically (New Straits Times, 2017).

Unbalanced land use distribution within areas in Kuala Lumpur is the new challenge that requires a more systematic planning and management of the city (National Urbanisation Plan 2, 2016). Furthermore, it causes an uneven spread of employment and land use control from the City Centre to the outer city . Big-scaled projects or mega projects also refer to the location in the city (Flyvbjerg, 2013). These projects are often developed in the core area or city centre which contributes to economic gains for the city. Linkages of transportation (Transit Oriented Development) influences the land use activity in 
Izuandi Yin, Jamalunlaili Abdullah

The Development Control of Urban Centre in Kuala Lumpur

urban centres and leads to an increasing need for services which result in higher taxes and traffic.

High intensity development results in rapid growth in the inner city, and limitation of city borders for every city in Malaysia. This study will analyse the tools of development control which influence the growth towards suburb areas. In 2014, land use area for Kuala Lumpur increased to 2584.11 in total compared to 2001 at only 1824.16 which resulting the land use area in total of $24,221.5$ hectare (Boori, Netzband, Voženílek, \& Choudhary, 2015a). This demonstrates that the growth of the city has increased. The city density of Kuala Lumpur has increased with urban expansion rapidly growing towards the east side of the city showing a fast growth (Boori, Netzband, Voženílek, \& Choudhary, 2015a). The built-up area from the city centre to $50 \mathrm{~km}$ outwards decreased in 2014 because of the high intensity and floor space in the city centre (Boori, Netzband, Voženílek, \& Choudhary, 2015b).

The link between a city's growth rank and urban land use expansion influenced by the urban hierarchy of the cities would result in a rapid urban growth in the country (Suharto Teriman, Yigitcanlar, \& Mayer, 2009). The increased built-up area in the inbound area and out-side the greenbelt area is the result of the provision of green space and the regional patterns of urban growth in urban areas (Paulsen, 2014). Furthermore, the degree of urban sprawl can be used either for single or multiple cities which typically result in the rapid sprawl of the cities that can be seen during the second decade of the developed city (Jiao. L, 2015). Population ageing has affected the land consumption (Kuala Lumpur Structure Plan 2020, 2004). The affected area is in a sub-urban area due to allocation of houses by senior citizens which reflect the reduction of land consumption.

\section{PURPOSE OF THE STUDY}

This study explains the analysis of intensity of development for each growth centre and these growth centres need to be ranked and classified by measuring the urban economic growth to get the finding for each growth development. This research will analyse urban growth and development control for a different hierarchy of urban centre in Kuala Lumpur. Urban growth development is related to several themes such as development control for the intensity of development. The intensity of development covers the development of the built-up area, land use within cities, zoning of land use, Gross Development Value, floor space, and development density where the major aspect contributes to the urban growth in the city centre. The research objective is based on a comparison between 11 urban growth patterns (City Centre and 10 District and Neighbourhood Centres). 
PLANNING MALAYSIA

Journal of the Malaysia Institute of Planners (2020)

\section{RESEARCH METHODS}

The method used in this study is the overlay technique using GIS data and matrix analysis to find the growth rank. The first stage is a preliminary study on the development of the urban centre to find the development growth of built up area in terms of the relation between the urban centre with surrounding district centres in Kuala Lumpur. It involves determining the study area focus on the growth centre of Kuala Lumpur Federal Territory based on secondary development information. The second stage is a literature review of theoretical studies related to the urban growth development and elements in development control.

The third stage is data collection. Both qualitative and quantitative approaches are used throughout this research. Primary data involves observation and mapping (Qualitative Method) in order to find the development intensity of the urban centre i.e. to calculate the actual plot ratio for each building, gross development value for each building, building height in terms of floor level, building floor space, and also the built up area for each lot. This observation also relates to other areas around the city centre to see the differences in the built-up areas that KL City Hall gives. Some areas will have high plot ratios and their importance will be considered. The other method used in this study is professional interviews (Qualitative Method) with government agencies to get the data related to the development control. A discussion is also carried out with a professional government worker (KL City Hall staff) to discover information related to built-up areas, defining the plot ratio, site decision for development, and the current situation in urban development in Kuala Lumpur.

The findings could help in discovering the growth of urban centres through development control. A comparative study is then conducted on the actual site to determine the measurement result of the elements in land use optimisation to find the level of growth for each urban centre. Land use development also has an influence on urban growth. This interrelationship creates the main element that responds to the development of urban growth for each urban centre and also economically influences the urban growth. Six elements have been analysed and identified to find the growth of each urban area based on this development control element. The element is plot ratio for each building that has its importance based on its growth centre. Built up area is analysed from the total building floor area and is influenced by the building height. The Gross Development Value (GDV) for development intensity comes from the estimation for each phase of development and the cost of the development. The total floor space area for buildings located in the urban centre is usually measured in square feet. The density of each urban centre is influenced by the number of population and the development within the city. Lastly, the mixed land use for each urban centre creates the pattern of growth. The analysis conducted through observation of the number of building floor, floor space \& level, data of GDV and distribution of plot ratio \& land use. Overlay technique GIS use to find the growth rank and 
Izuandi Yin, Jamalunlaili Abdullah

The Development Control of Urban Centre in Kuala Lumpur

the score of growth has been identified using the weight-age put for every element (landuse, total built-up area, average plot ratio, GDV and floor space). The scores are then used to rank each 11-growth centre and compare with the growth centre in KL City Plan 2020. The result shows some urban centre in the lower group actually can be promoted to the higher group as it meets the intensity.

\section{ANALYSIS \& FINDINGS}

There are 11 Growth Centre selected with the radius of the $1 \mathrm{~km}$ study area for each urban centre. These chosen areas in the district centre and neighbourhood centre are based on its importance of the commercial area in KL. It has been selected for comparison to other growth centre. The difference between the growth centre will be measured based on the intensity development of the selected area that contributes to the urban growth and urban economy for the city (Table 1).

Table 1: Selected growth centre

\begin{tabular}{ccc}
\hline Growth Centre & Urban Centre & Categories \\
\hline KL City Centre & City Centre of Kuala Lumpur & $\begin{array}{c}\text { Most intensive in land use, building } \\
\text { height and plot ratio in City Centre }\end{array}$ \\
\hline District Centre & $\begin{array}{c}\text { Damansara, Bukit Jalil, } \\
\text { Wangsa Maju, Bandar Tun } \\
\text { Razak, Bangsar, Datuk } \\
\text { Keramat, Sentul Raya }\end{array}$ & $\begin{array}{c}\text { Commercial area in the boundary of } \\
\text { District Centre that permissible } \\
\text { within City Centre }\end{array}$ \\
\hline $\begin{array}{c}\text { Neighbourhood } \\
\text { Centre }\end{array}$ & $\begin{array}{c}\text { Setiawangsa, Bandar Tasek } \\
\text { Selatan, Shamelin }\end{array}$ & $\begin{array}{c}\text { Commercial areas within the } \\
\text { residential neighbourhood }\end{array}$ \\
\hline & & Source: Kuala Lumpur Structure Plan 2020
\end{tabular}

The selection of the case study based on the existing District Centre in KL which is Damansara, Bukit Jalil, Wangsa Maju and Bandar Tun Razak. Three (3) other District Centres analysed are Bangsar, Datuk Keramat and Sentul Raya. While 3 other areas are the Neighborhood Center which is Setiawangsa, Bandar Tasek Selatan and Shamelin. The selection is based on the KL Structure Plan 2020 which has identified the City Centre, District Centre and the Neighborhood Center as selected by their own study in accordance to the criteria and the growth development that is presumed to have the potential to compete to be listed or ranked in a high growth centre. KL City Centre is already in Tier 1 or city centre growth areas so that it can be estimated to compare with other growth centres. However, the rest 10 growth centres are measured with intensity development and growth development by doing observation surveys to achieve the rank and comparison for each place. 


\section{Analysis on Population, Density and Floor Space}

The Kuala Lumpur City Plan strategic zone shows that Wangsa Maju- Maluri and Sentul- Manjalara were the highest density in KL with 8,163 person/square kilometre and expected to increase to 9,525 person/square kilometre by the year 2020. That resulted in $116 \%$ increase rate of 2005 in population density while the lowest density is Damansara-Penchala with 3,521 person/ square kilometre, which clearly shows that people move to the greater urban area because of the market force and job opportunities, in which the commercial floor space in the high-rise development along the main road and highways in the city where many businesses and offices and other uses of commercial activity are located. KL Structure Plan 2020 has specified the total of 41-million-meter square of floor space for commercial and projected the need up to a total of 65 -million-meter square by the year 2020 based on KL City Plan 2020. The committed Gross Floor Area (GFA) gained until the year 2005 is 14,916,008 square feet and expected to increase to $41,275,508$ square feet by the year 2020 . That resulted in a $277 \%$ increase which tripled the rate of 2005 in commercial floor space demand. To calculate this aspect of urban growth, the value of acreage for each lot and building lot has to be defined to get the percentage of plinth area and non-built up area for the lot. All development in the selected urban centre has to be calculated to obtain the Gross Development Value (GDV) and to know the value of land.

Table 2: Table 2. Urban Growth Analysis on Selected Growth Centre (1km radius)

\begin{tabular}{|c|c|c|c|c|c|c|c|c|}
\hline \multirow[t]{2}{*}{ Growth Centre } & \multirow{2}{*}{$\begin{array}{l}\text { Urban } \\
\text { Center }\end{array}$} & \multicolumn{3}{|c|}{ Land use (1 km from centre) } & \multirow{2}{*}{$\begin{array}{c}\text { Total } \\
\text { Built Up } \\
\text { Area } \\
\text { (Sqft) }\end{array}$} & \multirow{2}{*}{$\begin{array}{c}\text { Average } \\
\text { Plot } \\
\text { Ratio }\end{array}$} & \multirow{2}{*}{$\begin{array}{c}\text { GDV } \\
\text { (RM } \\
\text { million) }\end{array}$} & \multirow{2}{*}{$\begin{array}{l}\text { Floor } \\
\text { Space } \\
\text { (Sqft) }\end{array}$} \\
\hline & & $\begin{array}{c}\text { Area } \\
\text { (Acre) }\end{array}$ & Highest & Lowest & & & & \\
\hline KL City Centre & $\begin{array}{l}\text { Kuala } \\
\text { Lumpur } \\
\text { City Centre }\end{array}$ & 625.1 & $\begin{array}{l}\text { Commercial } \\
(35.4 \%)\end{array}$ & $\begin{array}{l}\text { Industry } \\
(0.03 \%)\end{array}$ & $1,888,711$ & $1: 8$ & $11,726.4$ & $17,668,700$ \\
\hline \multirow[t]{7}{*}{ District Centre } & Damansara & 581.4 & $\begin{array}{l}\text { Residential } \\
(39.4 \%)\end{array}$ & $\begin{array}{l}\text { Industry } \\
(0.20 \%)\end{array}$ & $1,109,287$ & $1: 4$ & $4,833.0$ & $5,966,315$ \\
\hline & Bukit Jalil & 630.6 & $\begin{array}{l}\text { Facility } \\
(20.0 \%)\end{array}$ & $\begin{array}{l}\text { Utility } \\
(0.06 \%)\end{array}$ & 558,177 & $1: 3$ & $3,265.4$ & $3,878,451$ \\
\hline & $\begin{array}{l}\text { Wangsa } \\
\text { Maju }\end{array}$ & 558.1 & $\begin{array}{l}\text { Residential } \\
(44.6 \%)\end{array}$ & $\begin{array}{l}\text { River } \\
(0.05 \%)\end{array}$ & 590,884 & $1: 2.5$ & $2,936.1$ & $5,680,272$ \\
\hline & $\begin{array}{l}\text { Bandar Tun } \\
\text { Razak }\end{array}$ & 767.6 & $\begin{array}{l}\text { Residential } \\
(28.9 \%)\end{array}$ & $\begin{array}{l}\text { Facility } \\
(0.80 \%)\end{array}$ & 551,419 & $1: 2.5$ & 3.294 .0 & $3,213,700$ \\
\hline & Bangsar & 576.6 & $\begin{array}{l}\text { Residential } \\
(48.4 \%)\end{array}$ & $\begin{array}{l}\text { Facility } \\
(0.10 \%)\end{array}$ & $1,138,221$ & $1: 5$ & $5,318.4$ & $7,274,800$ \\
\hline & $\begin{array}{l}\text { Datuk } \\
\text { Keramat }\end{array}$ & 515.3 & $\begin{array}{l}\text { Residential } \\
(33.1 \%)\end{array}$ & $\begin{array}{l}\text { Facility } \\
(0.20 \%)\end{array}$ & $1,100,938$ & $1: 4$ & $4,952.3$ & $5,607,700$ \\
\hline & Sentul Raya & 584.5 & $\begin{array}{l}\text { Residential } \\
(37.9 \%)\end{array}$ & $\begin{array}{l}\text { Amenity } \\
(0.40 \%)\end{array}$ & $1,102,809$ & $1: 4$ & $3,741.0$ & $5,711,625$ \\
\hline \multirow[t]{3}{*}{$\begin{array}{l}\text { Neighbourhood } \\
\text { Centre }\end{array}$} & Setiawangsa & 552.7 & $\begin{array}{l}\text { Residential } \\
(28.7 \%)\end{array}$ & $\begin{array}{l}\text { Facility } \\
(0.20 \%)\end{array}$ & 548,205 & $1: 2$ & $2,965.5$ & $3,213,700$ \\
\hline & $\begin{array}{l}\text { Bandar } \\
\text { Tasek } \\
\text { Selatan }\end{array}$ & 584.9 & $\begin{array}{l}\text { Residential } \\
(32.6 \%)\end{array}$ & $\begin{array}{l}\text { Facility } \\
(0.80 \%)\end{array}$ & 564,504 & $1: 3$ & $3,374.0$ & $4,031,476$ \\
\hline & Shamelin & 587.3 & $\begin{array}{l}\text { Residential } \\
(41.7 \%)\end{array}$ & $\begin{array}{l}\text { Facility } \\
(0.60 \%)\end{array}$ & 559,369 & $1: 3$ & $3,849.3$ & $3,957,900$ \\
\hline
\end{tabular}


Izuandi Yin, Jamalunlaili Abdullah

The Development Control of Urban Centre in Kuala Lumpur

Table 2 shows the urban growth analysis for selected growth centres. It includes calculation and measurement on plinth area and building level and acreage to get the total number of built-up areas. The data of the plinth area and level of the building has been gathered from the site observation which was conducted to estimate and measure the built up for every single development. Then the total up for every development has come with the total of built-up area for every urban growth centre.

The ranking for the built-up area is different according to the function of the growth centre. Leading the $1^{\text {st }}$ rank is KL (19.5\%), a city centre, followed by Bangsar (11.7\%), Damansara (11.5\%), Sentul Raya (11.4\%), Datuk Keramat (11.3\%) and Wangsa Maju (6.1\%) which are amongst the district centre conquering the $2^{\text {nd }}$ to the $6^{\text {th }}$ rank. While the $7^{\text {th }}$ and $8^{\text {th }}$ rank are the neighbourhood centre: Bandar Tasek Selatan (5.8\%) and Shamelin (5.7\%). The $9^{\text {th }}$ and $10^{\text {th }}$ rank are the district centre of Bukit Jalil $(5.7 \%)$ and Bandar Tun Razak (5.6\%), while the lowest rank (11 $\left.{ }^{\text {th }}\right)$ of builtup area based on growth centre is the neighbourhood centre of Setiawangsa $(5.6 \%)$. In reference to the ranking order, the result shows that the growth order is not according to the natural order of growth centre (presumably influences its total built up area for each urban centre), instead, the ranking shows that despite the $1^{\text {st }}$ until the $6^{\text {th }}$ ranking follows the natural order of growth centre, neighbourhood centres have increases their built up area, this allows neighbourhood areas to be ranked in the $7^{\text {th }}$ and $8^{\text {th }}$ rank (Bandar Tasek Selatan and Shamelin), ahead of the district centres in the $9^{\text {th }}$ and $10^{\text {th }}$ rank (Bukit Jalil and Bandar Tun Razak.

Matrix analysis used for each variable in growth criteria in $\mathrm{KL}$ which is in plot ratio, GDV, floor space and built up area score to determine the importance and the rank for each urban centre with the total score for the growth in KL is 220 . The highest growth score is KL City Centre with 40 total scores representing $18.2 \%$ of KL growth. Damansara with 22 total scores of $10 \%$ of overall growth, Bukit Jalil with 16 total score representing $7.3 \%$ from overall growth, the same can analysis is reflected by Wangsa Maju with 16 total score with 7.3\% from overall growth, Bandar Tun Razak with 13 total growth represents 5.9\% from overall growth, Bangsar with 26 total score represent $11.8 \%$ of overall growth. Furthermore, Datuk Keramat with a total growth score of 22 represents $10 \%$ of overall growth, and Sentul Raya with total scores 21 represent $9.5 \%$ of overall growth's score. Setiawangsa with a total growth score of 11 represents $5 \%$ of overall growth, and Bandar Tasek Selatan with a total score of 16 represent $7.2 \%$ of overall growth score. Last but not least is Shamelin with a total score of 17 representing $7.7 \%$ of overall growth. The score of every variable of 
growth which is plot ratio score with $61(27.7 \%)$ from overall variable growth score. Gross Development Value with a total score of 47 (21.4\%) from the overall variable growth score. Floor space total score and built up area total score were both 54 scores $(24.5 \%)$ and 58 scores $(26.4 \%)$.

\section{Finding on the growth of urban centre}

The $1^{\text {st }}$ rank of growth centre in KL is the Kuala Lumpur City Centre in City Centre Growth. Rank analysis shows the $2^{\text {nd }}$ rank is Bangsar followed by Damansara and Datuk Keramat that shares the position of the $3^{\text {rd }}$ rank, then the $4^{\text {th }}$ rank which is Sentul Raya and $5^{\text {th }}$ rank is Shamelin. However, the analysis shows that the $6^{\text {th }}$ rank is a neighbourhood centre, thus it shows that this urban centre is higher than urban centre in the $7^{\text {th }}$ rank which is Bandar Tun Razak that is of a District Centre. Shamelin has the potential to upgrade its growth centre from neighbourhood centre to district centre, while Bandar Tun Razak can be classified as a neighbourhood centre. While the remaining two urban centres in the Neighbourhood Centre which is Bandar Tasek Selatan and Setiawangsa is still classified as Neighbourhood Centre because their position in $6^{\text {th }}$ and $8^{\text {th }}$ rank respectively.

The area in KL CP 2020 (Bandar Tun Razak and Shamelin) and KLSP 2020 (Bandar Tun Razak, Datuk Keramat, Bangsar, Sentul Raya and Shamelin) is categorised as the area that has been affected to be transferred by looking at the growth rank. There is an area that is supposedly being classified as a Neighbourhood centre commercial in KLCP 2020 which is Bandar Tun Razak. Furthermore, Shamelin classified as a Neighbourhood Centre Commercial in KLCP 2020 has significance by its growth rank to be located in the District Centre Commercial group. A centre which is of higher growth compared to Bandar Tun Razak, which is Datuk Keramat, Bangsar, Sentul Raya and Shamelin were supposedly being ranked in District Centre. 


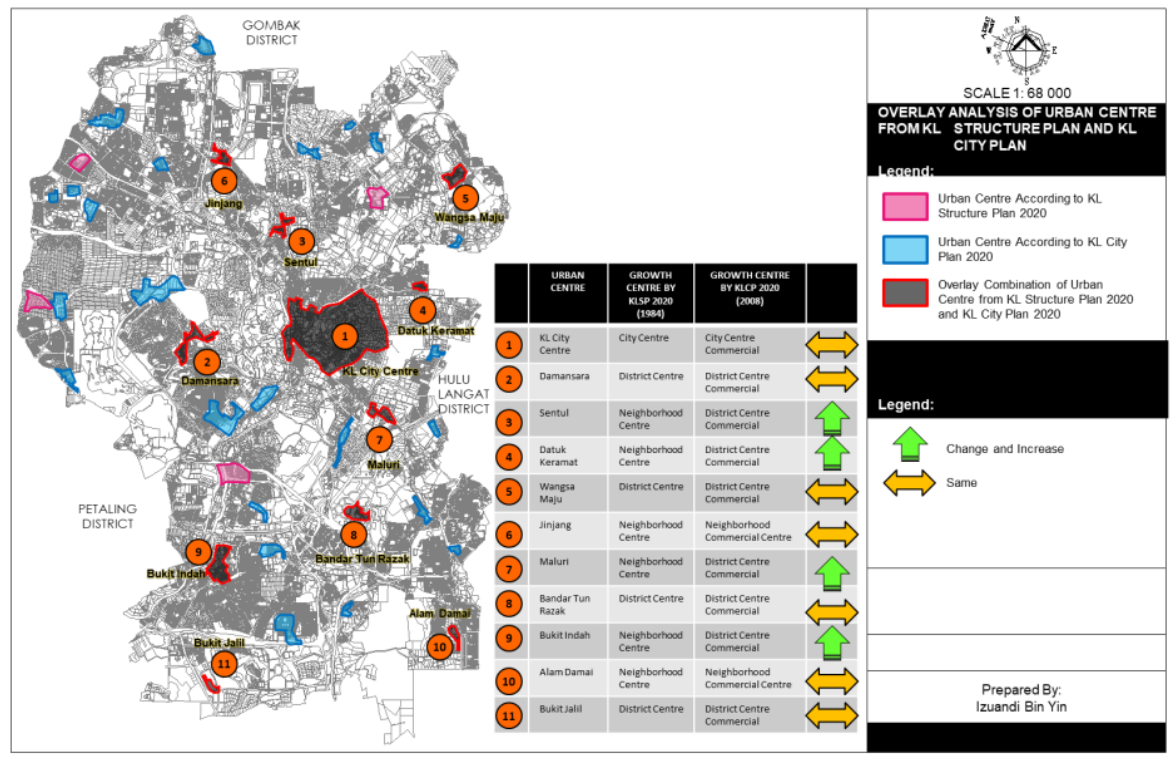

Figure 1: Overlay analysis of urban centre from KL structure plan and KL city plan Source: Kuala Lumpur Structure Plan 2020: A World Class City (2004) Kuala Lumpur City Plan 2020: Towards a World Class City (2008)

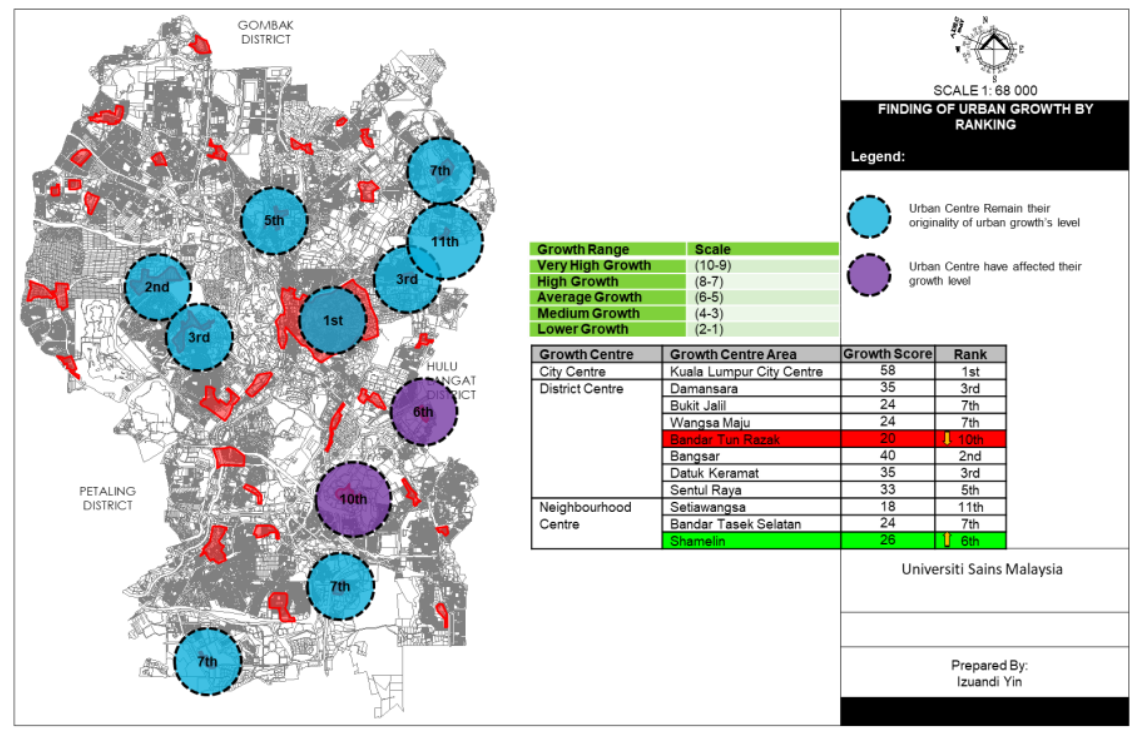

Figure 2: Finding of urban growth by rank

Figure 1 shows the result of an overlay analysis for the urban centres from KLSP 2020 and urban centres from KLCP 2020. The result has identified 11 urban 
centres in the overlay and shows a mismatch of growth centres as employed by Kuala Lumpur City Hall. This analysis also has answered a part of the main problem statement for this research. The result shows that seven of the urban centres are stagnant or not experiencing any changes while four other urban centres (Sentul, Datuk Keramat, Maluri and Bukit Indah) have increased in growth from Neighbourhood Centre to District Centre Commercial. Next is the identification of land use for each urban centre with categories for its own use of land and building use. There is a growth centre that has been affected by the significance of the growth in its rank in Kuala Lumpur. The area that has been highlighted or ranked in the table inside Figures 1 and 2 both in KL CP 2020 and KLSP 2020 is categorised as an area that has been affected and to be transferred by looking at the growth rank. The areas in KLCP 2020 (Bandar Tun Razak and Shamelin) and KLSP 2020 (Bandar Tun Razak, Datuk Keramat, Bangsar, Sentul Raya and Shamelin) are categorised as the areas that are to be transferred by looking at the growth rank. Based on Figure 2, the top ranked growth centre in Kuala Lumpur is Kuala Lumpur City Centre in City Centre Growth. Rank analysis defines Bangsar at second followed by Damansara (third) and Datuk Keramat (fourth) who share the same growth score at third position, fifth is Sentul Raya and sixth is Shamelin. However, the analysis shows that the sixth position is come from Neighbourhood Centre's group, which means that this urban centre is ranked higher than Bandar Tun Razak (tenth) in the District Centre group decreasing the growth score. Meaning that anything can happen (lower group of urban centres can overtake the score in upper rank group) in urban centre hierarchy when development control has been analysed through the growth analysis. Shamelin has the potential to upgrade its growth centre status from Neighbourhood Centre to District Centre, while Bandar Tun Razak should be classified as a Neighbourhood Centre compared to District Centre in KLCP 2020. The two remaining urban centres in the Neighbourhood Centre group i.e. Bandar Tasek Selatan (seventh) and Setiawangsa (eleventh) can still be classified as neighbourhood centres base on their score. The centres with higher growth rank's score compared to Bandar Tun Razak is Datuk Keramat (third), Bangsar (second), Sentul Raya (fifth) and Shamelin (sixth)

The analysis that has been done to identify the growth of Kuala Lumpur shows that it can be measured from the land use optimisation which is the estimation of plot ratio, floor space, measuring the built-up area from the development, and gross development value for the intensity of development for each urban centre. The findings clearly show that the urban centre classification in KLCP and KLSP is outdated. There are neighbourhood centre areas that need to be classified in the district centre group because they are growing faster than areas in the district centre group. 
Izuandi Yin, Jamalunlaili Abdullah

The Development Control of Urban Centre in Kuala Lumpur

\section{CONCLUSION}

Development control has influenced the growth of urban centres especially in terms of location and intensity of development. Physical development that has been approved with planning permission allows alteration of buildings and create a higher density for proposed developments. The practise of identifying the capacity of development control in the said urban centre can identify the latest rank and upgrade or downgrade the growth centre. This is important to measure the growth extension which can identify the growth direction through the locational of urban centre.

\section{ACKNOWLEDGEMENTS}

The authors would like to thank our main sponsor, Universiti Sains Malaysia through Short Term Grant (304/PPBGN/6315259) to avail this study. The credit also goes to School of Housing Building and Planning, Universiti Sains Malaysia, Pulau Pinang for the encouragement and support during the preparation of this paper.

\section{REFERENCES}

Boori, M. K., Netzband, M., Voženílek, V., \& Choudhary, K. (2015). Urban Growth In Last Three Decades In Kuala Lumpur, Malaysia. Urban Remote Sensing Event (JURSE), IEEE, 2015, ISSN 2334-0932.

Boori, M. K., Netzband, M., Choudhary, K., \& Voženílek, V. (2015). Monitoring and Modeling Of Urban Sprawl Through Remote Sensing and GIS in Kuala Lumpur Malaysia. Ecological Processes, 4, 2015.

Flyvbjerg, B. (2013). Mega Delusional: The Curse of the Megaproject. New Scientist, 2829.

Jiao , L. (2015). Urban Land Density Function: A New Method To Characterize Urban Expansion. Landscape and Urban Planning Journal, 139, 26-39.

Kuala Lumpur Structure Plan 2020: A World Class City (2004). Dewan Bandaraya Kuala Lumpur, 2004. ISBN 9839983245, 9789839983241

Kuala Lumpur City Plan 2020: Towards a World Class City. Dewan Bandaraya Kuala Lumpur, 2008. ISBN 9839983288, 9789839983289

National Urbanization Plan 2 (NUP) 2016. Jabatan Perancangan Bandar dan Desa Semenanjung Malaysia. Kementerian Kesejahteraan Bandar, Perumahan Dan Kerajaan Tempatan. Julai 2016. ISBN 978-967-12812-3-9

New Strats Times (8 Jun 2017), National Urbanization Plan 2 (NUP2). (Accessed February 2018) Retrieved from https://www.pressreader.com/malaysia/newstraits-times/20170608/281582355602030

Paulsen, K. (2014). Geography, policy or market? New evidence on the measurement and causes of sprawl (and infill) in US metropolitan regions. Urban Studies Journal, 51(12), 2629-2645.

Prime Minister's Department (2016). Economic Transformation Programme, Anual Report 2016.Performance Management and Delivery Unit (PEMANDU). 
Quigley, J. M. (2006). Urban Economics. UC Berkeley: Berkeley Program on Housing and Urban Policy. Retrieved from https://escholarship.org/uc/item/0jrop2tk

Siedentop, S., Fina, S., \& Krehl, A. (2016). Greenbelts in Germany's regional plans-An effective growth management policy?. Landscape and Urban Planning Journal, 145, 71-82.

Teriman, S., Yigitcanlar, T., \& Severine, M. (2009). Urban sustainability and growth management in south-east Asian city regions: the case of Kualalumpur and Hongkong. Planning Malaysia Journal of the Malaysian Institute of Planners, 7(1), 47-68.

Town and Country Planning Act 1976 (Act 172) (Malaysia)

Yusup, M., Arshad, A.F., Marzukhi, M.A., Abdullah, Y.A. (2018). Temporary Planning Permission In Development Control System For Urban Development, Planning Malaysia: Journal of Malaysian Institute of Planners, 16(3),143-155.

Received: January 2020. Accepted: $22^{\text {th }}$ May 2020 